\title{
Input and output of dissolved organic and inorganic nitrogen in subtropical forests of South China under high air pollution
}

\author{
Y. T. Fang ${ }^{1}$, P. Gundersen ${ }^{2}$, J. M. Mo ${ }^{1}$, and W. X. Zhu ${ }^{3}$ \\ ${ }^{1}$ South China Botanical Garden, the Chinese Academy of Sciences, Guangzhou, 510650, China \\ ${ }^{2}$ Forest \& Landscape Denmark, Faculty of Life Sciences, University of Copenhagen, Hørsholm Kongevej 11, 2970 Hørsholm, \\ Denmark \\ ${ }^{3}$ Department of Biological Sciences, State University of New York - Binghamton, Binghamton, NY 13902, USA
}

Received: 30 August 2007 - Published in Biogeosciences Discuss.: 12 November 2007

Revised: 30 January 2008 - Accepted: 6 February 2008 - Published: 7 March 2008

\begin{abstract}
The nitrogen (N) emissions to the atmosphere and $\mathrm{N}$ deposition to forest ecosystems are increasing rapidly in Southeast Asia, but little is known about the fates and effects of elevated $\mathrm{N}$ deposition in forest ecosystems in this warm and humid region. Here we report the concentrations and fluxes of dissolved inorganic (DIN) and organic N (DON) in precipitation, throughfall, surface runoff and soil solution for three subtropical forests in a region of South China under high air pollution over two years (2004 and 2005), to investigate how deposited $\mathrm{N}$ is processed, and to examine the importance of DON in the $\mathrm{N}$ budget. The precipitation DIN input was $32-34 \mathrm{~kg} \mathrm{~N}^{-1} \mathrm{yr}^{-1}$. An additional input of $18 \mathrm{~kg} \mathrm{~N} \mathrm{ha}^{-1} \mathrm{yr}^{-1}$ as DON was measured in 2005, which to our knowledge is the highest DON flux ever measured in precipitation. A canopy uptake of DIN was indicated in two young conifer dominated forests $(72-85 \%$ of DIN input reached the floor in throughfall), whereas no uptake occurred in an old-growth broadleaf forest. The DON fluxes in throughfall were similar to that in precipitation in all forests. In the younger forests, DIN was further retained in the soil, with $41-63 \%$ of precipitation DIN leached below the $20-\mathrm{cm}$ soil depth. Additionally, about half of the DON input was retained in these forests. The $\mathrm{N}$ retention in two young aggrading forests (21-28 $\mathrm{kg} \mathrm{N} \mathrm{ha}^{-1} \mathrm{yr}^{-1}$ ) was in accordance with the estimates of $\mathrm{N}$ accumulation in biomass and litter accretion. In the old-growth forest, no $\mathrm{N}$ retention occurred, but rather a net loss of $8-16 \mathrm{~kg} \mathrm{~N}^{-1} \mathrm{yr}^{-1}$ from the soil was estimated. In total up to $60 \mathrm{~kg} \mathrm{~N} \mathrm{ha}^{-1} \mathrm{yr}^{-1}$ was leached from the old-growth forest, indicating that this forest was completely $\mathrm{N}$ saturated and could not retain addi-
\end{abstract}

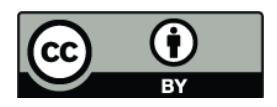

Correspondence to: Y. T. Fang

(fangyt@scbg.ac.cn) tional anthropogenic $\mathrm{N}$ inputs. We found that the majority of DIN deposition as well as of DIN leaching occurred in the rainy season (March to August) and that monthly DIN concentrations and fluxes in leaching were positively related to those in throughfall in all three forests, implying that part of the $\mathrm{N}$ leaching was hydrologically driven. Our results suggest that long-term high $\mathrm{N}$ deposition has caused elevated $\mathrm{N}$ leaching in all three forest types although most pronounced in the old-growth forest where wood increment was negligible or even negative. $\mathrm{N}$ availability even exceeded the biotic $\mathrm{N}$ demand in the young aggrading forests, with intensive rain in the growing season further enhancing $\mathrm{N}$ leaching in these forests.

\section{Introduction}

Increases in the deposition of atmospheric nitrogen $(\mathrm{N})$ influence $\mathrm{N}$ cycling in forest ecosystems and can result in several negative consequences including acidification and leaching of nitrate into groundwater (Aber et al., 1989). A large body of research to assess the risk and consequence of $\mathrm{N}$ saturation has been carried out in temperate regions, where industrial development occurred earliest (e.g. Gundersen et al., 2006). Forest ecosystems have been shown to vary in their responses to increased $\mathrm{N}$ deposition. The timing and magnitude of response are thought to depend largely on the nutrient status of the forest and how close it is to $\mathrm{N}$ saturation (Gundersen et al., 1998; Aber et al., 2003). On the large scale, different climate regime (temperature and precipitation) is considered to affect forest $\mathrm{N}$ cycling rate and subsequently the response to anthropogenic $\mathrm{N}$ inputs (Hall and Matson, 2003; Lohse and Matson, 2005). On more local

Published by Copernicus Publications on behalf of the European Geosciences Union. 
scale, differences in soil $\mathrm{N}$ pool size, species composition, stand age and land-use history may be major factors controlling the response pattern, because they influence the balance between $\mathrm{N}$ availability and demand (Fenn et al., 1998; Lovett et al., 2002; Kirstensen et al., 2004; Magill et al., 2004).

Atmospheric $\mathrm{N}$ deposition increases in densely populated areas of tropical and subtropical Asia due to the intensification of fossil fuel use and expansion of industrial and agricultural activities. Several authors have raised their concerns over the consequences of $\mathrm{N}$ enrichment on forest ecosystems in these warm and humid regions (Matson et al., 1999; Galloway et al. 2002; Chen and Mulder, 2007a). Elevated deposition of $\mathrm{N}$ in precipitation greater than $25 \mathrm{~kg} \mathrm{~N} \mathrm{ha}^{-1} \mathrm{yr}^{-1}$, the threshold above which elevated $\mathrm{N}$ leaching usually occurs in temperate forests (e.g. MacDonald et al. 2002), has already been reported for areas in southern China with rapid economic growth (Fan and Hong, 2001; Zhang, 2006; Chen and Mulder, 2007a; Luo et al., 2007), and it is expected to increase further in the coming decades (Zheng et al., 2002). However, little is known about how precipitation $\mathrm{N}$ interacts with forest canopies in warm and humid climates. Also the current $\mathrm{N}$ status and $\mathrm{N}$ process rates are unknown for forest ecosystems in these regions (Chen and Mulder, 2007a, b).

In temperate forests the response to elevated $\mathrm{N}$ deposition has been described in stages of decreasing biological control over the N cycle (Stoddard, 1994). Nitrate leaching first appears in the dormant season when biological demand is small, then gradually appears also in the growing season as plant and microbial demands for $\mathrm{N}$ become saturated. The responses of subtropical forest ecosystems in China may differ from those in temperate zone because of different climate, species composition and soil properties (Chen and Mulder, 2007). Due to its position near the Pacific Ocean in the east and the Indian Ocean in the south, south China has a monsoon climate with a high abundance of heat, light, and water throughout the rainy season when a major fraction of the $\mathrm{N}$ deposition also occurs (Zhou and Yan, 2001). Elevated $\mathrm{N}$ deposition thus coincide with the most productive season and may be retained by biological processes, on the other hand high water fluxes occur during rain events which may favour leaching of deposition $\mathrm{N}$. The balance between biological uptake, contact time and flow rate determine the fate of deposition $\mathrm{N}$ in the rainy season, whereas deposition $\mathrm{N}$ will most likely be retained throughout the dry season where plants are still productive and flows are minimal.

In the present study we have measured $\mathrm{N}$ input and $\mathrm{N}$ leaching at three subtropical forest types in the Dinghushan Biosphere Reserve (DHSBR) in southern China over two years to improve our understanding of $\mathrm{N}$ cycling in warm humid forest ecosystems. Short-term measurements of bulk precipitation in periods throughout the 1990's revealed atmospheric $\mathrm{N}$ deposition of $20-38 \mathrm{~kg} \mathrm{~N} \mathrm{ha}^{-1} \mathrm{yr}^{-1}$ in precipitation to this reserve (Huang et al., 1994; Zhou and Yan, 2001; Mo et al., 2002). We recently reported similar dissolved inorganic N (DIN) deposition in bulk precipitation in 2004 (Fang et al., 2008). Here we have continued these measurements but including also the analysis of dissolved organic N (DON) input in bulk and wet-only precipitation.

The forests types used, one mature monsoon evergreen broadleaf forest (old-growth) and two young forests (a pine forest and a pine-broadleaf mixed forest), are included in an ongoing $\mathrm{N}$ addition experiment (Fang et al., 2006). The oldgrowth forest is a regional climax type and has been protected for more than 400 years by monks in the nearby temples (Wang et al., 1982). The two young forests both originated from the 1930's clear-cut and subsequent pine plantation but developed differently later due to different patterns of human disturbance (Wang et al., 1982). We expect that these forest types would respond differently to the elevated $\mathrm{N}$ deposition. The old-growth forest is likely to be $\mathrm{N}$-saturated but the two younger ones may be still N-limited (Fang et al., 2006). However the canopy differences (oldgrowth broadleaf vs. two mostly conifer canopies) may modify the response due to higher pollution interception in the conifer canopies than the broadleaf ones. Here we present two years of data from control plots in these forests to explore how ecosystem $\mathrm{N}$ retention has been affected by at least 15 years of high atmospheric $\mathrm{N}$ deposition. The importance of DON in the $\mathrm{N}$ budgets was examined in the second year, since this form of $\mathrm{N}$ has been commonly ignored in studies of warm humid ecosystems, although studies from other forest ecosystems have indicated its potential importance (Perakis and Hedin, 2002; Cornell et al., 2003).

\section{Materials and methods}

\subsection{Site description}

The study site is located in Dinghushan Biosphere Reserve (DHSBR) in the middle part of Guangdong province, South China $\left(112^{\circ} 10^{\prime} \mathrm{E}\right.$ and $\left.23^{\circ} 10^{\prime} \mathrm{N}\right)$. This reserve is $20 \mathrm{~km}$ east of the relatively small city Zhaoqing (330 thousand inhabitants), about $90 \mathrm{~km}$ west of the metropolitan Guangzhou (10 million inhabitants), and $180 \mathrm{~km}$ northwest of Hong Kong (7 million inhabitants). The climate is warm and humid. The mean annual rainfall of $1927 \mathrm{~mm}$ has a distinct seasonal pattern, with 75\% falling from March to August and only 6\% from December to February (Huang and Fan, 1982). Mean annual relative humidity is $80 \%$ and mean annual temperature is $21.0^{\circ} \mathrm{C}$, with average temperatures in the coolest month (January) and the hottest month (July) of $12.6^{\circ} \mathrm{C}$ and $28.0^{\circ} \mathrm{C}$, respectively (Huang and Fan, 1982).

A survey conducted in 2003 showed that in the old-growth evergreen broadleaf forest the major species were Castanopsis chinensis, Machilus chinensis, Schima superba, Cryptocarya chinensis, Syzygium rehderianum in the canopy and sub-canopy layers, which represented up to $80 \%$ of total basal area. Both young forests were originated from the 1930's clear-cut and subsequent pine plantation (Fang 
Table 1. Characteristic of the mineral soil $(0-10 \mathrm{~cm})$ in the pine, mixed and old-growth forests at DHSBR in southern China.

\begin{tabular}{lcccc}
\hline Parameter & Pine forest & Mixed forest & Old-growth forest & $\mathrm{P}$ \\
\hline Bulk density $\left(\mathrm{g} \mathrm{cm}^{-3}\right)$ & $1.16(0.03) \mathrm{ab}$ & $1.22(0.03) \mathrm{a}$ & $0.98(0.06) \mathrm{b}$ & 0.026 \\
$\mathrm{pH}$ & $4.04(0.04) \mathrm{a}$ & $3.95(0.01) \mathrm{a}$ & $3.83(0.02) \mathrm{b}$ & 0.003 \\
Total C $(\%)$ & $2.8(0.3) \mathrm{b}$ & $2.6(0.3) \mathrm{b}$ & $4.6(0.23) \mathrm{a}$ & 0.004 \\
Total N $(\%)$ & $0.11(0.01) \mathrm{b}$ & $0.10(0.01) \mathrm{b}$ & $0.19(0.01) \mathrm{a}$ & 0.001 \\
$\mathrm{C} / \mathrm{N}$ ratio & $25(1.1) \mathrm{ab}$ & $28(0.7) \mathrm{a}$ & $22.1(1.3) \mathrm{b}$ & 0.05 \\
Total P $(\%)$ & $0.043(0.003) \mathrm{b}$ & $0.044(0.004) \mathrm{b}$ & $0.059(0.003) \mathrm{a}$ & 0.024 \\
Extractable $\mathrm{NH}_{4}^{+}\left(\mathrm{mg} \mathrm{N} \mathrm{kg}^{-1}\right)$ & $3.20(0.35) \mathrm{a}$ & $3.03(0.22) \mathrm{a}$ & $2.04(0.04) \mathrm{a}$ & 0.027 \\
Extractable $\mathrm{NO}_{3}^{-}\left(\mathrm{mg} \mathrm{N} \mathrm{kg}^{-1}\right)$ & $2.48(0.43) \mathrm{b}$ & $2.80(0.40) \mathrm{b}$ & $11.70(1.00) \mathrm{a}$ & $<0.001$ \\
\hline
\end{tabular}

SE in parentheses, $n=3$. Significant differences between forests were indicated by different letters. Data from Fang et al. (2006).

et al., 2006). The colonization from natural dispersal of regional broadleaf species has changed plant composition in the mixed forest (main species were Pinus massoniana, Schima superba, and Castanopsis chinensis), while the pine forest is dominated by Pinus massoniana under continuous human disturbances (generally the harvesting of understory and litter) (Mo et al., 2003). The old-growth forest had a basal area of almost twice $\left(26.2 \mathrm{~m}^{2} \mathrm{ha}^{-1}\right)$ those in the pine and mixed forests (14.0 and $\left.13.8 \mathrm{~m}^{2} \mathrm{ha}^{-1}\right)$, but less litter accumulation in the forest floor $\left(8.9,23\right.$ and $20 \mathrm{Mg} \mathrm{ha}^{-1}$ in the old-growth, pine and mixed forests, respectively; Fang et al., 2006). Basal area in the old-growth forest might be underestimated because particularly big trees were not included in our plots.

The topography is highly heterogeneous, with slopes ranging from $15^{\circ}$ to $35^{\circ}$. The soil is lateritic red earth formed from sandstone (He et al., 1982). The soil depths vary among forests. In the old-growth forest the soil depth ranges from $30 \mathrm{~cm}$ to $70 \mathrm{~cm}$. The soil is about $40 \mathrm{~cm}$ deep in the mixed forest, and generally less than $40 \mathrm{~cm}$ in the pine forest. The old-growth forest had significant higher concentrations of total $\mathrm{C}, \mathrm{N}$ and $\mathrm{P}$, and extractable $\mathrm{NO}_{3}^{-}$, but lower soil $\mathrm{pH}, \mathrm{C} / \mathrm{N}$ ratio, soil bulk density and extractable $\mathrm{NH}_{4}^{+}$concentration than the pine and mixed forests (Table 1). Soil condition in the pine and mixed forests did not differ significantly (Table 1).

\subsection{Sampling protocol}

We sampled both bulk and wet-only precipitation in an open area in the reserve. Bulk precipitation was collected using two open glass funnels $(15 \mathrm{~cm}$ in diameter), each connected to a $2.5 \mathrm{~L}$ sampling bottle with black polypropylene tubes. Wet-only precipitation was taken from a standard automatic wet-only collector (a $300 \mathrm{~mm}$ diameter stainless steel container for wet deposition and a $150 \mathrm{~mm}$ diameter glass container for dry deposition, APS-3, Hunan Xianglan Ltd. China) located near the bulk collectors.
To collect throughfall, five collectors made of longitudinally split PVC pipes (intercept area $0.8 \mathrm{~m}^{2}$ for each collector) were laid out randomly about $1.3 \mathrm{~m}$ above the ground in each forest. Each collector was connected to two $50 \mathrm{~L}$ sealed buckets (avoiding overflow) with black polypropylene tubes. The contribution from stemflow was negligible $(<4 \%$ of througfall N; Fang et al., 2008).

In each of the three forest types, we established three control plots (each $10 \mathrm{~m} \times 20 \mathrm{~m}$ ) for this $\mathrm{N}$ input-output study (total 9 plots). Soil solutions from $20 \mathrm{~cm}$ below the surface were sampled from each plot in all three forest types. Two zero tension tray lysimeters $\left(755 \mathrm{~cm}^{2}\right.$ per tray) were installed in each plot in the spring of 2003 to collect soil solutions. Each lysimeter was connected to a $5 \mathrm{~L}$ bottle using the steep slope of the sites to facilitate sampling. Previous study showed that more than $70 \%$ of the fine root biomass $(<5 \mathrm{~mm})$ was distributed in the upper $20 \mathrm{~cm}$ soil in the mixed and old-growth forests (Wen et al., 1999). Thus, the $\mathrm{N}$ leached in soil solution estimated in this study was probably greater than that actually leached from the systems, since a small fraction of $\mathrm{N}$ was likely to be further retained in the deeper soil. Soil solution at $40 \mathrm{~cm}$ depth obtained with ceramic suction cups were collected in 2004 , but were terminated due to technical difficulties. The measurement revealed that annual volumeweighted DIN concentrations at $40 \mathrm{~cm}$ were slightly lower than at $20 \mathrm{~cm}$ soil depth in the pine forest $(2.5 \mathrm{vs} .3 .0 \mathrm{mg}$ $\mathrm{N} \mathrm{L}^{-1}$ ), and the difference was somewhat more pronounced in the old-growth forest (5.2 vs. $6.8 \mathrm{mg} \mathrm{N} \mathrm{L}^{-1}$; Fang et al., 2008). In addition, since the plots are situated on steep slopes, one plot in both the pine and old-growth forests was delimited hydrologically by plastic and concrete barriers to sample and quantify surface runoff (overland flow). Surface runoff was not collected from the mixed forest due to its similarities of amount of floor litter and slope degree with those in the pine forest.

Water samples were taken from January 2004 to December 2005. Precipitation samples were generally collected following a rainy day or a series of rainy days. We took soil solution samples twice a month, with one sampling date around 


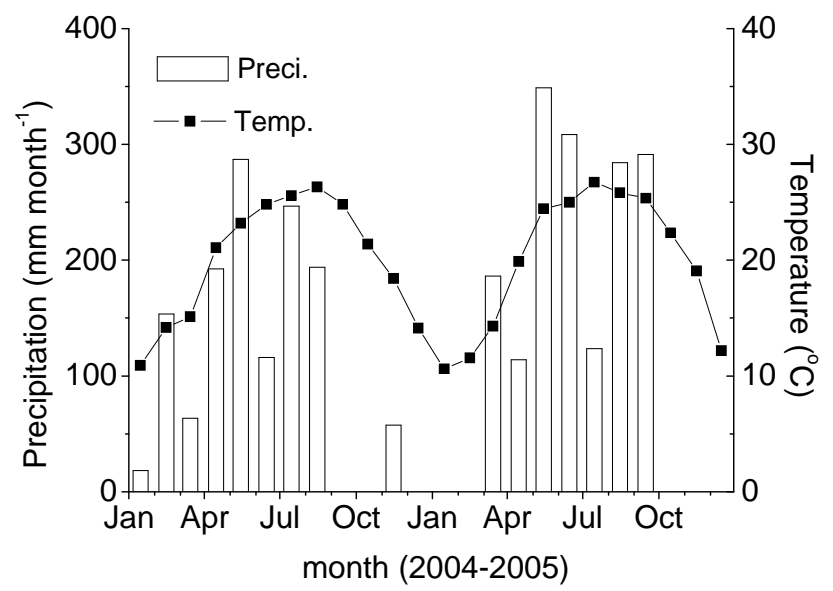

Fig. 1. Monthly precipitation and monthly mean air temperature at DHSBR in southern China.

the middle and the other at the end of month. Throughfall and surface runoff samples were taken in the first and third week of each month. Additional throughfall samples were taken again when we collected soil solution (if precipitation had occurred), and pooled (volume-weighted) with their respective regular samples before chemical analysis. For all throughfall and soil solution samples, the water volume was recorded before sampling. All collectors were washed with distilled water immediately after each collection.

\subsection{Sampling processing and analysis}

Samples were filtered within $24-48 \mathrm{~h}$ of collection through $0.45 \mu \mathrm{m}$ filters in the laboratory, and then stored in plastic bottles at $4{ }^{\circ} \mathrm{C}$ until chemical analysis. Concentrations of dissolved inorganic $\mathrm{N}\left(\mathrm{DIN}=\mathrm{NH}_{4}^{+}+\mathrm{NO}_{3}^{-}\right.$) were determined for all samples. Total dissolved N (TDN) concentration was determined for samples collected in 2005. Concentration of $\mathrm{NH}_{4}^{+}$was analyzed by the indophenol blue method followed by colorimetry, and $\mathrm{NO}_{3}^{-}$was analyzed after cadmium reduction to $\mathrm{NO}_{2}^{-}$, followed by sulfanilamide-NAD reaction (Liu et al., 1996). Total $\mathrm{N}$ was determined using persulphate oxidation to $\mathrm{NO}_{3}^{-}-\mathrm{N}$ followed by colorimetric determination (Liu et al., 1996). Dissolved organic N (DON) concentration was calculated as the differences between TDN and DIN.

\subsection{Calculations and statistics}

The precipitation and air temperature data used in this study were from the weather station in the reserve (Fig. 1). The recorded volumes of precipitation, throughfall, and soil solution in each plot were multiplied by their concentrations for the same period to determine $\mathrm{N}$ fluxes in $\mathrm{kg} \mathrm{ha}^{-1}$, which then summed to get monthly and annual fluxes. We used estimated surface runoff volumes according to the observed relationship between precipitation and surface runoff to calculate
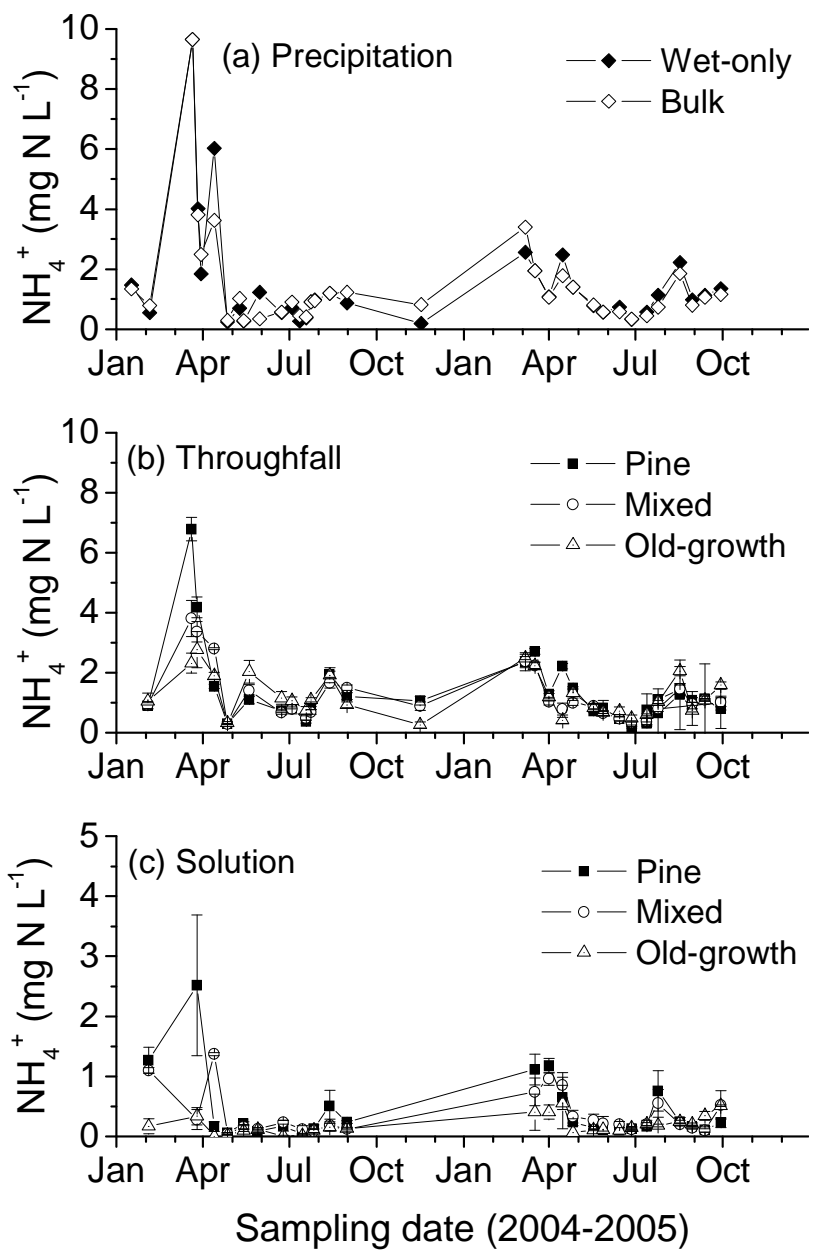

Fig. 2. $\mathrm{NH}_{4}^{+}$concentrations in precipitation (a) were measured in both wet-only collectors (automatically open during rain events) and bulk collectors (open continuously). Throughfalls (b) and soil solutions (c) were collected from Pine, Mixed, and Old-growth forests separately.

its $\mathrm{N}$ fluxes (Fang et al., 2008). Monthly mean concentrations and fluxes were used to explore the relationships among precipitation, throughfall and soil solution for each forest type, using correlation analysis. One-way ANOVA with Tukey's$\mathrm{b}$ post hoc was used to identify the effects of forest type and year on annual fluxes of $\mathrm{NH}_{4}^{+}-\mathrm{N}$ and $\mathrm{NO}_{3}^{-}-\mathrm{N}$ in throughfall and soil solution. One-way ANOVA was also carried out to examine the effect of forest type on annual DON fluxes in 2005. All analyses were conducted using SPSS 10.0 for Windows. Statistical significant differences were set with $P$ values $<0.05$ unless otherwise stated. 


\section{Results}

\subsection{Precipitation}

There were no obvious differences in the concentrations of $\mathrm{NH}_{4}^{+}, \mathrm{NO}_{3}^{-}$and DON between bulk precipitations and wet-only collections (Figs. 2-4), suggesting little contribution of dry deposition to overall $\mathrm{N}$ inputs during the sampling periods. Thus, the means of two bulk collectors and one wet-only collector in the open area were used in the statistical analysis thereafter. Ammonium and $\mathrm{NO}_{3}^{-}$concentrations showed a similar seasonal pattern during the course of our study (Figs. 2, 3), as confirmed by their highly significant linear correlation $\left(r^{2}=0.68, n=34, P<0.001\right)$. Their concentrations were highest in March/April, and then decreased considerably after the start of the rainy season, and reached the lowest levels in May/June (Figs. 2, 3). Annual volume-weighted concentration of $\mathrm{NH}_{4}^{+}$was markedly higher in $2004\left(1.8 \mathrm{mg} \mathrm{N} \mathrm{L}^{-1}\right)$ than that in $2005(1.1 \mathrm{mg} \mathrm{N}$ $\left.\mathrm{L}^{-1}\right)$. For $\mathrm{NO}_{3}^{-}$annual volume-weighted concentration was similar over the two years (both around $0.8 \mathrm{mg} \mathrm{N} \mathrm{L}^{-1}$ ).

Despite $330 \mathrm{~mm}$ more precipitation $(25 \%)$ in the second year, annual DIN input in precipitation was $5 \%$ less in the second than in the first year (Table 2). Ammonium was the dominant form of DIN input in precipitation with a contribution of $68 \%$ and $56 \%$ in the first and second year, respectively (Table 2). In both years, $82-83 \%$ of the precipitation fell in the rainy season (March to August, Fig. 1). Correspondingly, from $80 \%$ to $92 \%$ of DIN input in precipitation occurred in this period of the year (Fig. 5). Monthly DIN inputs were positively correlated to the mean DIN concentrations $\left(r^{2}=0.56, P=0.001, n=16\right)$ but were weakly correlated to the monthly precipitation amount $\left(r^{2}=0.20, P=0.082\right)$.

Precipitation DON concentration (measured in 2005 only) showed a different seasonal fluctuation from DIN (Figs. 24). As a result, it did not correlate with either $\mathrm{NH}_{4}^{+}$or $\mathrm{NO}_{3}^{-}(P>0.05)$, which indicated that DIN and DON might have different sources at our site. Dissolved organic $\mathrm{N}$ input amounted to $17.8 \mathrm{~kg} \mathrm{~N} \mathrm{ha}^{-1} \mathrm{yr}^{-1}$, about $36 \%$ of total dissolved $\mathrm{N}$ (TDN) input (47.6 $\mathrm{kg} \mathrm{N} \mathrm{ha}^{-1}$ in 2005, Table 2). Annual volume-weighted concentration of DON was $1.1 \mathrm{mg}$ $\mathrm{N} \mathrm{L}^{-1}$. Monthly DON inputs correlated positively with the concentrations $\left(r^{2}=0.85, P=0.003, n=7\right)$ but were independent of monthly precipitation amount.

\subsection{Throughfall}

In throughfall, the seasonal patterns of both $\mathrm{NH}_{4}^{+}$and $\mathrm{NO}_{3}^{-}$ concentrations were similar to those in precipitation (Figs. 2, 3). The concentrations of $\mathrm{NO}_{3}^{-}$in small samples collected in December 2004 were particularly high (Fig. 3), which might be due to dry deposition in a two months drought period before the sampling (Fig. 1), but could also be due to mineralization/nitrification of litter in the canopy. Thus the concentration in precipitation at the same sampling date was used
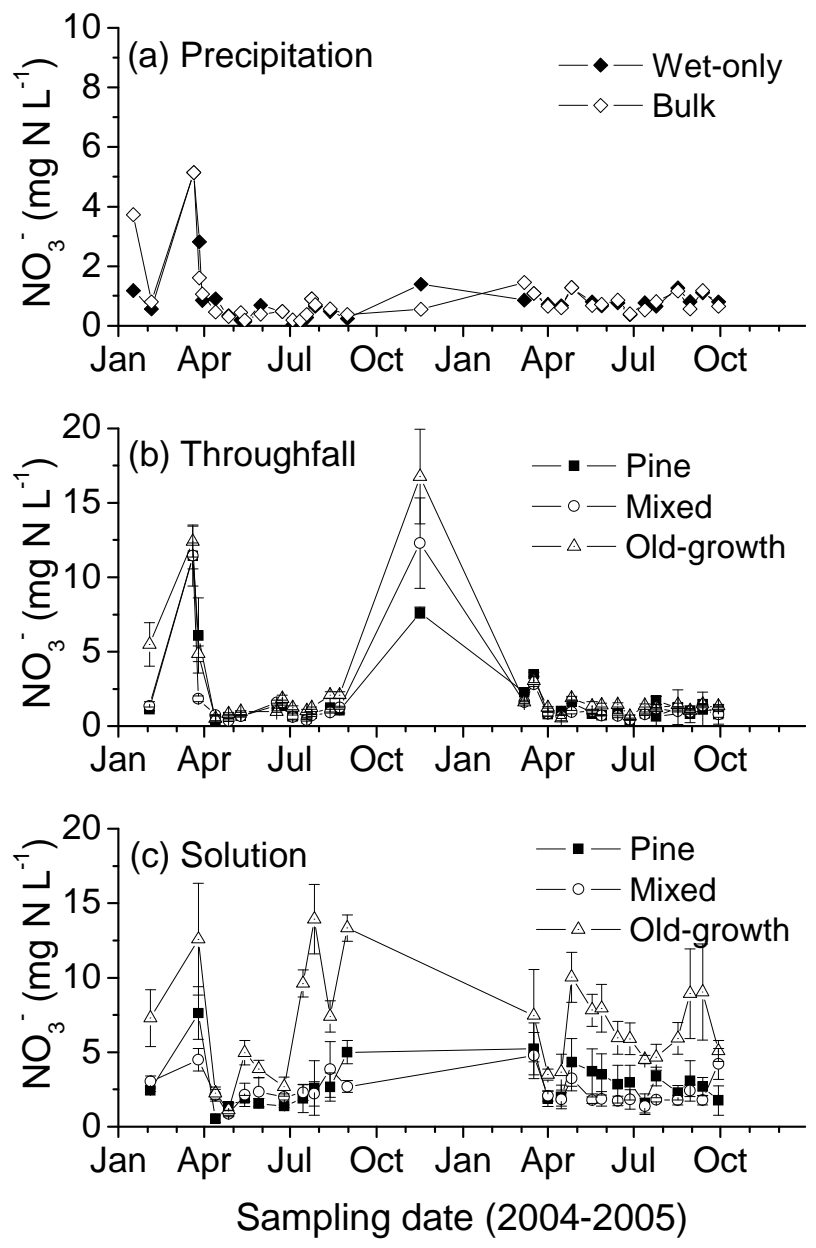

Fig. 3. $\mathrm{NO}_{3}^{-}$concentrations in precipitation (a) were measured in both wet-only collectors (automatically open during rain events) and bulk collectors (open continuously). Throughfalls (b) and soil solutions (c) were collected from Pine, Mixed, and Old-growth forests separately.

to calculate the $\mathrm{N}$ input in throughfall. This led to an underestimate of the total $\mathrm{N}$ input, but throughfall in that month accounted for only 16-24 mm, namely $0.9-2 \%$ of annual water fluxes. Monthly mean DIN concentrations in throughfall showed significant correlations with that in precipitation for all three forests $(P<0.001)$.

Annual volume-weighted concentrations of $\mathrm{NH}_{4}^{+}$in throughfall were 1.1 to $1.5 \mathrm{mg} \mathrm{N} \mathrm{L}^{-1}$ in 2004 and $0.9-1.1 \mathrm{mg}$ $\mathrm{N} \mathrm{L}^{-1}$ in 2005 , which were lower than those observed in precipitation. The tree canopy of all forest types was thereby a sink for $\mathrm{NH}_{4}^{+}$, removing $4.7-10.4 \mathrm{~kg} \mathrm{~N} \mathrm{ha}^{-1} \mathrm{yr}^{-1}$ in 2004 and 3.6-6.6 $\mathrm{kg} \mathrm{N} \mathrm{ha}^{-1} \mathrm{yr}^{-1}$ in 2005, respectively (Table 2). Annual volume-weighted concentrations of $\mathrm{NO}_{3}^{-}$were always higher in throughfall $\left(1.0-1.7 \mathrm{mg} \mathrm{N} \mathrm{L}^{-1}\right.$ in 2004 and $0.9-1.3 \mathrm{mg} \mathrm{N} \mathrm{L}^{-1}$ in 2005) than in precipitation, and annual throughfall $\mathrm{NO}_{3}^{-}$input was close to that of precipitation input (in both the pine and mixed forest) or increased (in 
Table 2. Annual fluxes of water $(\mathrm{mm})$ and nitrogen $\left(\mathrm{kg} \mathrm{N} \mathrm{ha}^{-1} \mathrm{yr}^{-1}\right)$ in precipitation, throughfall, surface runoff and the soil solution (leachate from $20 \mathrm{~cm}$ depth) in the pine, mixed and old-growth forests at DHSBR in southern China.

\begin{tabular}{|c|c|c|c|c|c|c|c|c|c|c|}
\hline & \multicolumn{4}{|c|}{2004} & \multicolumn{5}{|c|}{2005} & \multirow[b]{2}{*}{ TDN } \\
\hline & Water & $\mathrm{NH}_{4}^{+}-\mathrm{N}$ & $\mathrm{NO}_{3}^{-}-\mathrm{N}$ & DIN & Water & $\mathrm{NH}_{4}^{+}-\mathrm{N}$ & $\mathrm{NO}_{3}^{-}-\mathrm{N}$ & DIN & DON & \\
\hline $\begin{array}{l}\text { Precipitation } \\
\text { Throughfall }(\mathrm{n}=5)\end{array}$ & 1327 & 23.2 & 10.9 & 34.2 & 1657 & 17.8 & 13.8 & 31.6 & 17.8 & 49.5 \\
\hline Pine forest & $1120(27)$ & $12.8(0.6)$ & $12.6(1.0) \mathrm{b}$ & $24.6(1.4) b$ & $1315(15)$ & $12.9(0.7)$ & $13.9(0.6) \mathrm{b}$ & $26.8(1.3) \mathrm{b}$ & $18.2(2.1)$ & $44.9(3.2) \mathrm{ab}$ \\
\hline Mixed forest & $1135(8)$ & $15.2(1.0)$ & $11.6(0.9) \mathrm{b}$ & $26.1(1.8) \mathrm{b}$ & $1229(12)$ & $11.2(0.7)$ & $11.5(0.4) \mathrm{c}$ & $22.8(1.0) \mathrm{b}$ & $14.6(2.2)$ & $37.3(2.9) \mathrm{b}$ \\
\hline $\begin{array}{l}\text { Old-growth forest } \\
\text { Surface runoff }(n=1)\end{array}$ & $1126(22)$ & $16.5(1.5)$ & $18.9(2.1) \mathrm{a}$ & $35.4(3.4) \mathrm{a}$ & 1333(57) & $14.2(1.1)$ & $17.4(0.9) \mathrm{a}$ & $31.6(1.5) \mathrm{a}$ & $20.1(0.8)$ & $51.7(2.1) \mathrm{a}$ \\
\hline Pine forest & 106 & 1.6 & 2.7 & 4.3 & 133 & 1.1 & 2.4 & 3.6 & 1.1 & 4.7 \\
\hline $\begin{array}{l}\text { Old-growth forest } \\
\text { Solution }(n=3)\end{array}$ & 226 & 1.6 & 2.2 & 3.8 & 283 & 1.3 & 3.8 & 5.1 & 2.1 & 7.2 \\
\hline Pine forest & $397(58)$ & $1.6(0.5)$ & $9.0(3.0) \mathrm{b}$ & $10.6(3.5) \mathrm{b}$ & $515(49)$ & $1.2(0.2)$ & $15.5(6.3) \mathrm{b}$ & $16.6(6.3) \mathrm{b}$ & $8.4(3.4)$ & $25.0(9.7) \mathrm{b}$ \\
\hline Mixed forest & $377(31)$ & $1.5(0.2)$ & $8.5(1.4) b$ & $10.0(1.6) \mathrm{b}$ & $469(137)$ & $1.1(0.5)$ & $9.5(2.8) \mathrm{b}$ & $10.6(3.3) \mathrm{b}$ & $6.5(2.0)$ & $17.1(5.2) \mathrm{b}$ \\
\hline Old-growth forest & $527(78)$ & $0.6(0.1)$ & $37.2(7.7) \mathrm{a}$ & $37.8(7.7) \mathrm{a}$ & $601(28)$ & $1.2(0.1)$ & $41.7(7.1) \mathrm{a}$ & $43.0(7.1) \mathrm{a}$ & $16.9(3.9)$ & $59.8(10.7)$ a \\
\hline
\end{tabular}

SE in parentheses. Significant differences among three forest types were indicated by different letters, $P<0.05$.

the old-growth forest) after the interaction with tree canopies (Table 2). Consequently, a DIN uptake in the tree canopy on the order of 5 to $9 \mathrm{~kg} \mathrm{~N} \mathrm{ha}^{-1} \mathrm{yr}^{-1}$ must have occurred in the two young forests, which represented from $15 \%$ to $28 \%$ of their total DIN input in precipitation. But, in the old-growth forest, which had a broadleaf canopy, $\mathrm{N}$ fluxes remained unchanged (Table 2).

Throughfall DON concentrations exhibited a similar seasonality with that in precipitation (Fig. 4), indicating that DON in precipitation might be a main source of throughfall DON flux. Like in precipitation, there were no significant relationships between DON and $\mathrm{NH}_{4}^{+}$or between DON and $\mathrm{NO}_{3}^{-}$in throughfall in any forest. Throughfall DON inputs varied from 14.6 to $20.1 \mathrm{~kg} \mathrm{~N} \mathrm{ha}^{-1} \mathrm{yr}^{-1}$, and accounted for about $40 \%$ of TDN inputs across the forest types (Table 2). Annual volume-weighted DON concentration in throughfall was $1.2-1.5 \mathrm{mg} \mathrm{N} \mathrm{L}^{-1}$.

\subsection{Surface runoff}

Surface runoff (overland flow) was collected from the pine and mature forests, but not from the mixed forest (see Sect. 2.2). Concentrations of $\mathrm{NH}_{4}^{+}-\mathrm{N}$ were slightly lower than those of $\mathrm{NO}_{3}^{-}-\mathrm{N}$ and $\mathrm{DON}$ in both forests (data not shown). Losses via surface runoff were lower than those via seepage leaching (see below) and the difference between forests was minor relative to the difference of seepage leaching (Table 2). From 3.6 to $5.1 \mathrm{~kg} \mathrm{~N} \mathrm{ha}^{-1} \mathrm{yr}^{-1}$ as DIN and $1.1-2.1 \mathrm{~kg} \mathrm{~N} \mathrm{ha}^{-1} \mathrm{yr}^{-1}$ as DON (2005) were lost via surface runoff (Table 2).

\subsection{Soil solution}

Both $\mathrm{NH}_{4}^{+}$and $\mathrm{NO}_{3}^{-}$concentrations in soil solution at $20 \mathrm{~cm}$ depth had seasonal patterns comparable to those in through- fall (Figs. 2, 3). But the relationship between throughfall and soil solution concentration was forest-specific. In the pine and mixed forests, the seasonal changes of solution chemistry were close to those in the throughfall and the correlations were highly significant $(P<0.001$ and $P=0.003$, respectively). The old-growth forest had a larger seasonal variability in soil solution chemistry. Furthermore, a marked increase in $\mathrm{NO}_{3}^{-}$concentration was observed in some months with high precipitation amount (for example, April, May, August and September of 2005, Fig. 3). Consequently, in this forest monthly mean concentrations in throughfall and solution was only marginally correlated $(P=0.06)$.

We also found that soil solution $\mathrm{NO}_{3}^{-}$concentration was generally higher in 2005 than in 2004, particularly in the oldgrowth and pine forests (Fig. 3). Increased concentration in the second year might be caused by $330 \mathrm{~mm}$ more precipitation (Fig. 1), which might favour the soil nitrification. Active nitrification had been observed in the mineral soil in the pine and old-growth forests, but not in the mixed forest (author unpublished data). Annual volume weighted concentrations of $\mathrm{NO}_{3}^{-}$ranged from 2.0 to $7.1 \mathrm{mg} \mathrm{N} \mathrm{L}{ }^{-1}$, whereas $\mathrm{NH}_{4}^{+}$ concentrations were 0.1 to $0.5 \mathrm{mg} \mathrm{N} \mathrm{L}^{-1}$. The seasonal pattern of monthly DIN leaching followed those of throughfall input (Figs. 6, 7), as indicated by the significant relationships between leaching losses and throughfall inputs (Fig. 8). The leaching rate of DIN was higher in the old-growth forest than in the other two, as shown by a steeper slope of the regression line in Fig. 8a.

In the pine and mixed forests, from 10.0 to $16.6 \mathrm{~kg} \mathrm{~N}$ $\mathrm{ha}^{-1} \mathrm{yr}^{-1}$ were leached as DIN, which were $37-62 \%$ of $\mathrm{N}$ deposition in throughfall. However, the N-rich old-growth forest lost significantly more $\mathrm{N}$ due to its higher soil solution $\mathrm{NO}_{3}^{-}$level than the two young forests (Table 2); DIN and DON leached in this forest was 2.6-4.4 and 2.2-2.6 

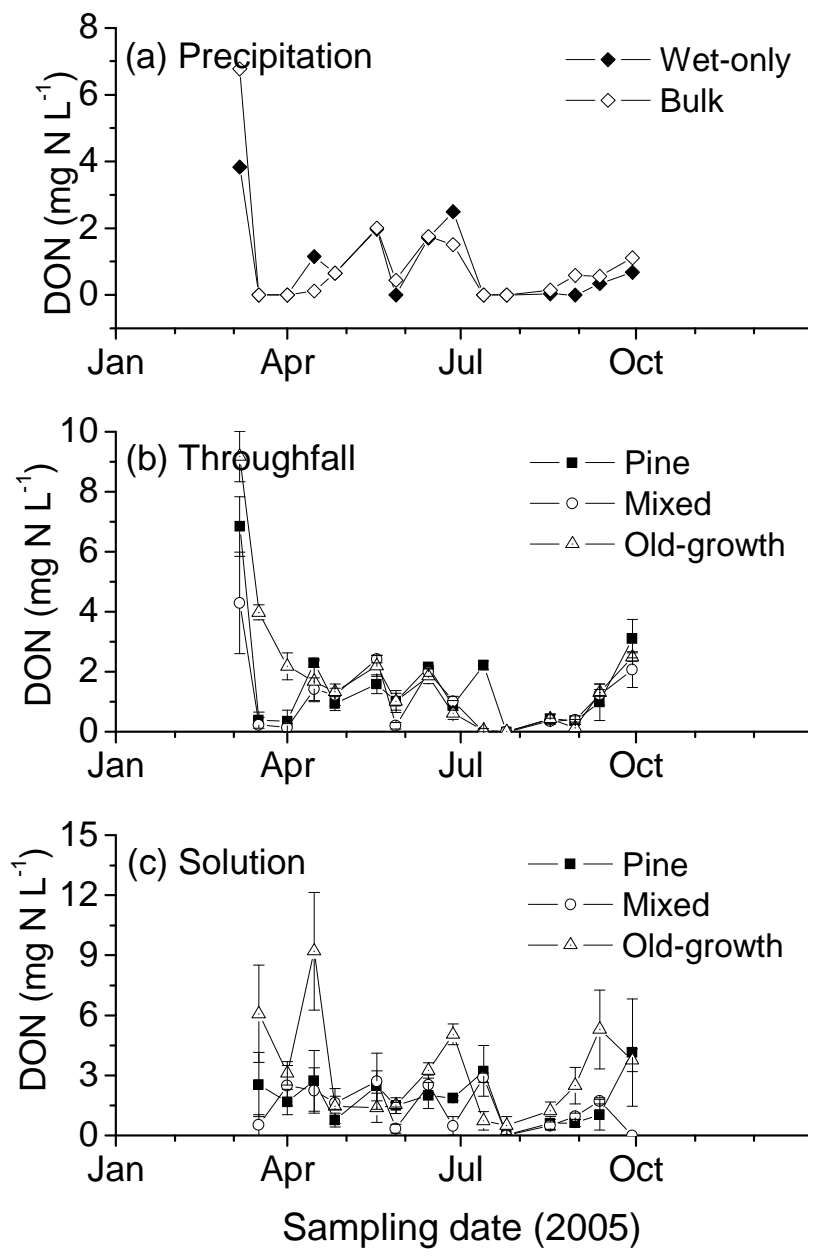

Fig. 4. DON concentrations in precipitation (a) were measured in both wet-only collectors (automatically open during rain events) and bulk collectors (open continuously). Throughfalls (b) and soil solutions (c) were collected from Pine, Mixed, and Old-growth forests separately. DON concentration was measured in 2005 only.

times higher than in the two young forests, respectively (Table 2). Annual DIN leaching loss was measured to $37.8 \mathrm{~kg} \mathrm{~N}$ $\mathrm{ha}^{-1} \mathrm{yr}^{-1}$ in 2004, similar to the throughfall input (Table 2). A higher DIN loss $\left(43.0 \mathrm{~kg} \mathrm{~N} \mathrm{ha}^{-1} \mathrm{yr}^{-1}\right)$ was observed in 2005 , partly due to higher precipitation amount, and it was $11 \mathrm{~kg} \mathrm{~N} \mathrm{ha}^{-1} \mathrm{yr}^{-1}$ in excess of its throughfall input.

DON leached in 2005 was 8.4 to $16.9 \mathrm{~kg} \mathrm{~N} \mathrm{ha}^{-1} \mathrm{yr}^{-1}$, and accounted for $28-38 \%$ of the TDN leached and $42-84 \%$ of its input in throughfall, respectively (Table 2). Annual volume-weighted DON concentration was 1.7 to $3.2 \mathrm{mg} \mathrm{N}$ $\mathrm{L}^{-1}$, which also was higher than those in throughfall. Seasonal variation of DON concentration generally followed those for DIN, and a significant but weak correlation of DIN and DON concentration in soil solution was found across all samplings in all three forests $\left(r^{2}=0.094, P=0.048, n=126\right)$, but this relationship was not significant when analyzed for each individual forest. Monthly DON leaching was posi-

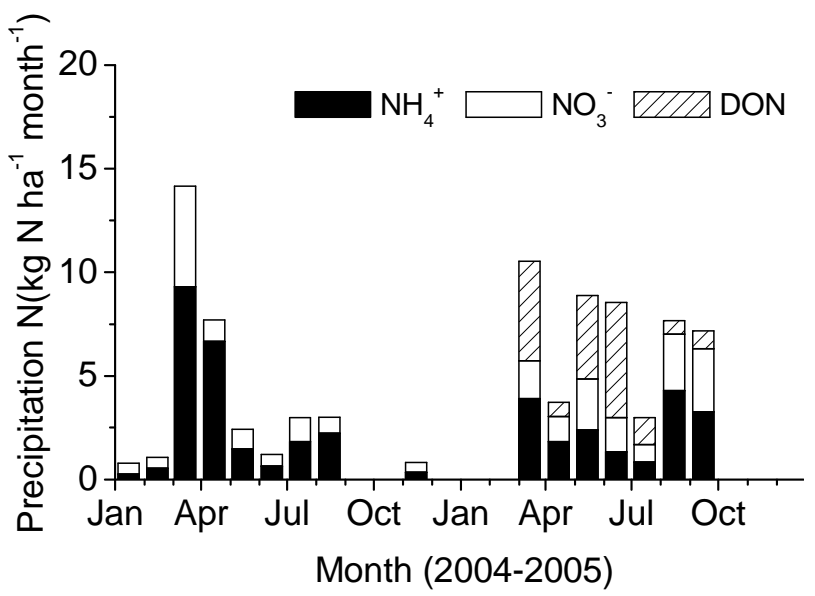

Fig. 5. Monthly fluxes of $\mathrm{NH}_{4}^{+}, \mathrm{NO}_{3}^{-}$and $\mathrm{DON}$ in precipitation at DHSBR in southern China. DON flux was measured in 2005 only.

Table 3. Total leaching loss and retention of nitrogen $(\mathrm{kg} \mathrm{N}$ $\mathrm{ha}^{-1} \mathrm{yr}^{-1}$ ) of precipitation inputs in the pine, mixed and oldgrowth forests at DHSBR in southern China.

\begin{tabular}{|c|c|c|c|c|}
\hline & \multirow{2}{*}{$\begin{array}{l}2004 \\
\text { DIN }\end{array}$} & \multicolumn{2}{|c|}{2005} & \multirow[b]{2}{*}{ TDN } \\
\hline & & DIN & DON & \\
\hline \multicolumn{5}{|c|}{ Total N leaching losses (surface runoff plus leaching solution) } \\
\hline Pine forest & 15 & 20 & 9 & 29 \\
\hline Mixed forest & 14 & 14 & 8 & 22 \\
\hline Old-growth forest & 42 & 48 & 19 & 67 \\
\hline \multicolumn{5}{|c|}{ Ecosystem $\mathrm{N}$ retention of precipitation input } \\
\hline Pine forest & 19 & 12 & 9 & 21 \\
\hline Mixed forest & 20 & 18 & 10 & 28 \\
\hline Old-growth forest & -8 & -16 & -1 & -17 \\
\hline
\end{tabular}

Note: surface runoff $\mathrm{N}$ fluxes in the pine forest was used to estimate those in the mixed forest, due to their similar amount of floor litter and similar landscape. The surface runoff $\mathrm{N}$ fluxes were a minor component compared to leaching in the younger forests, and a tiny fraction in the old-growth forest (see Table 2).

tively correlated with throughfall input in the mixed forest (Fig. 8b).

\subsection{Total $\mathrm{N}$ leaching and $\mathrm{N}$ retention}

Total DIN leaching losses (surface runoff plus seepage leaching in soil solution) from the upper $20 \mathrm{~cm}$ soil was estimated at $14-20 \mathrm{~kg} \mathrm{~N} \mathrm{ha}^{-1} \mathrm{yr}^{-1}$ in the two young forests, and at $42-$ $48 \mathrm{~kg} \mathrm{~N} \mathrm{ha}^{-1} \mathrm{yr}^{-1}$ in the old-growth forest (Table 3). Total DON leaching losses varied from 8 to $19 \mathrm{~kg} \mathrm{~N} \mathrm{ha}^{-1} \mathrm{yr}^{-1}$, with the old-growth being twice the amount of the other two (Table 3). In the two young forests, 22 and $28 \mathrm{~kg} \mathrm{~N} \mathrm{ha}^{-1} \mathrm{yr}^{-1}$ or $41 \%$ and $55 \%$ of precipitation TDN input in 2005 was retained in the upper $20 \mathrm{~cm}$ soil and through plant uptake, 


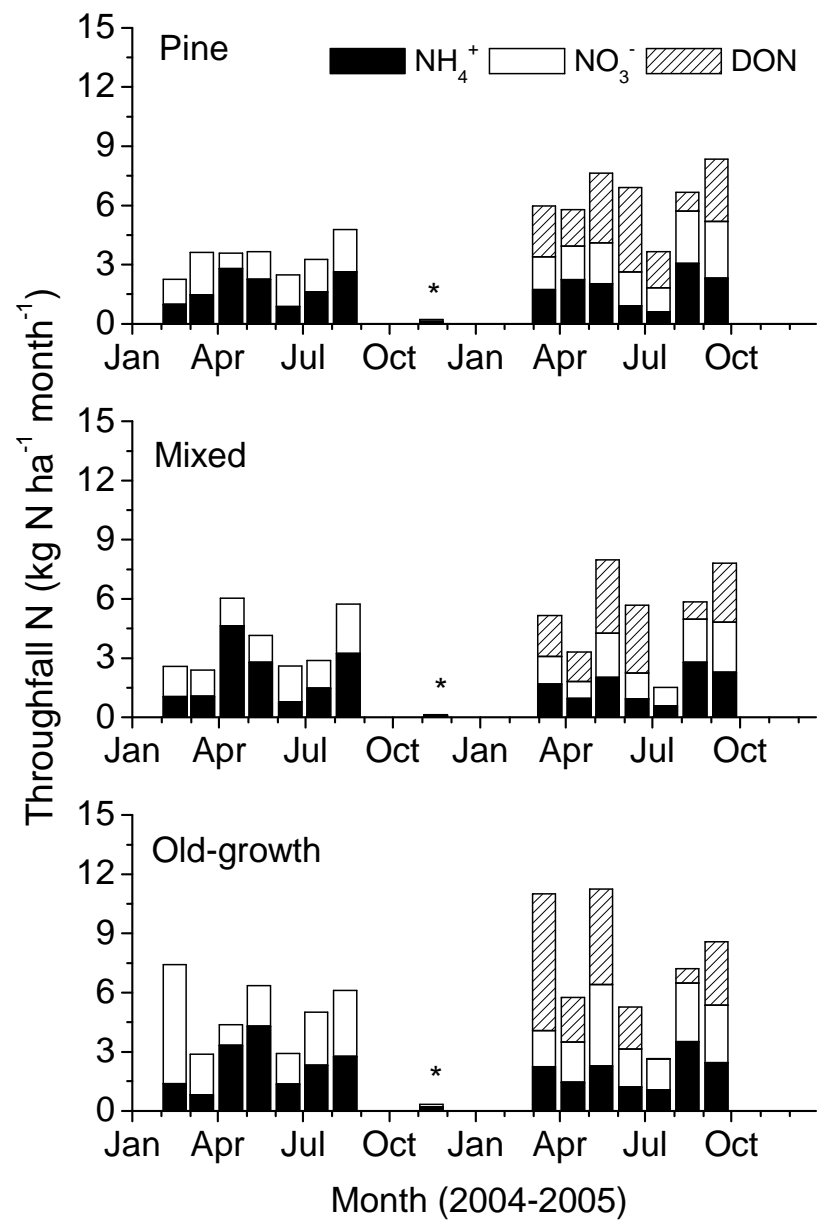

Fig. 6. Monthly fluxes of $\mathrm{NH}_{4}^{+}, \mathrm{NO}_{3}^{-}$and DON in throughfall in the pine, mixed and old-growth forests from DHSBR in southern China. DON flux was measured in 2005 only. * Concentration of DIN in precipitation was used to calculate throughfall $\mathrm{N}$ input in that month (see the text).

while no retention, but a net loss was found in the old-growth forest (Table 3). These retention estimates based on inputoutput budgets also account for the potential gaseous loss of $\mathrm{N}$ by denitrification. Gaseous losses as $\mathrm{N}_{2} \mathrm{O}$ were measured at nearby plot and estimated at $3.2 \pm 1.2 \mathrm{~kg} \mathrm{~N} \mathrm{ha}^{-1} \mathrm{yr}^{-1}$ for the three forest types (Tang et al., 2006).

\section{Discussion}

\subsection{Wet $\mathrm{N}$ deposition}

We did not observe marked differences in $\mathrm{N}$ concentrations between wet-only and bulk precipitation. No difference in concentrations of $\mathrm{NH}_{4}^{+}-\mathrm{N}$ and $\mathrm{NO}_{3}^{-}-\mathrm{N}$ between wet-only and bulk precipitation was also observed at another site in Guangzhou area (Aas et al., 2007). With high humidity and

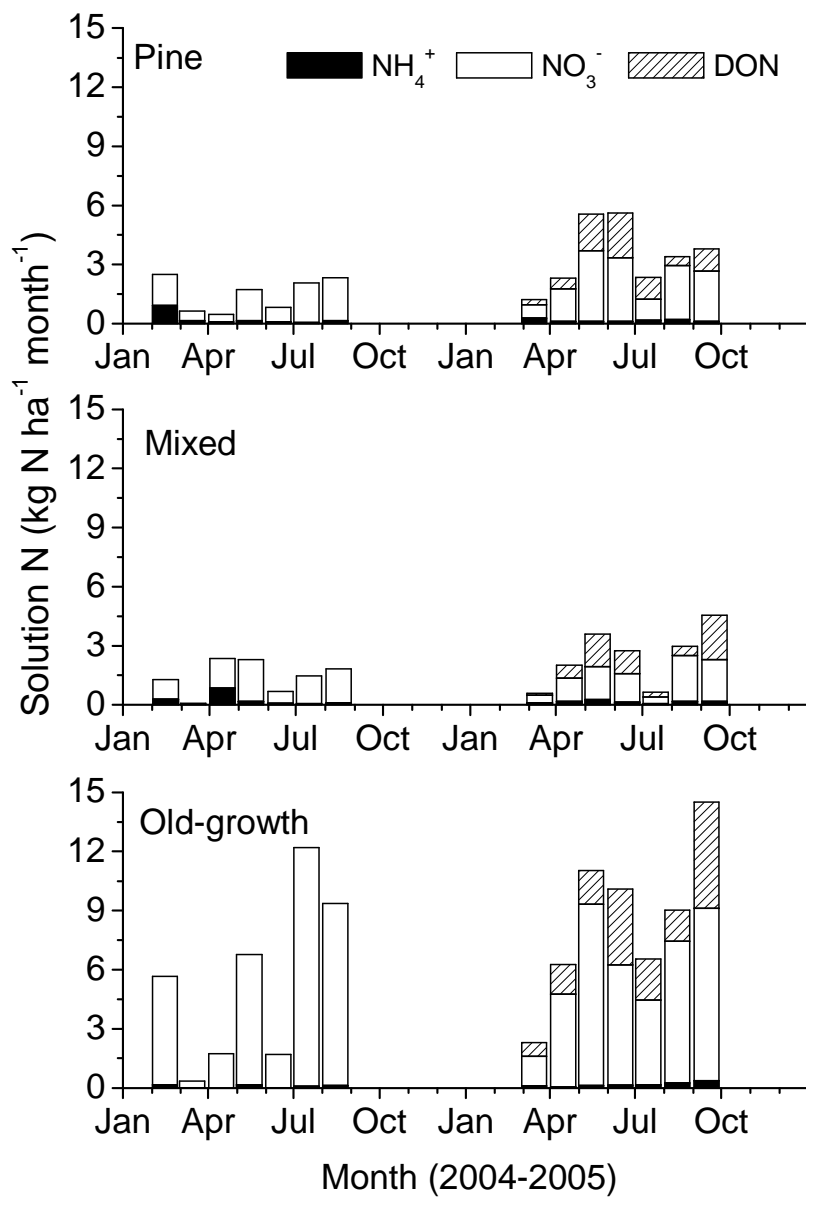

Fig. 7. Monthly fluxes of $\mathrm{NH}_{4}^{+}, \mathrm{NO}_{3}^{-}$and $\mathrm{DON}$ in soil solution from the pine, mixed and old-growth forests from DHSBR in southern China. DON flux was measured in 2005 only.

frequent rainfalls in the wet season of this region, wet deposition is likely to dominate the total atmospheric deposition.

Precipitation DIN input was estimated at 31.6 and $34.2 \mathrm{~kg}$ $\mathrm{N} \mathrm{ha}^{-1} \mathrm{yr}^{-1}$ in the two years studied (Table 2), which are comparable to the highest deposition levels observed in Europe (MacDonald et al., 2002; Kristensen et al., 2004), but higher than those observed in most forests in North America (Fenn et al., 1998; Campbell et al., 2004) and Japan (Ohte et al., 2001). Precipitation DIN deposition at our site is higher than some other parts of southern China as well (Gan et al., 1995; Chen et al., 1997; Sha et al., 2002; Chen and Mulder, 2007a), except in Zhangzhou of Fujiang Province and Shanghai where average deposition of 37 and $58 \mathrm{~kg} \mathrm{~N} \mathrm{ha}^{-1} \mathrm{yr}^{-1}$ in precipitation were reported (Xiao et al., 2005; Zhang, 2006).

Consistent with our result, $\mathrm{NH}_{4}^{+}$is the main form of inorganic $\mathrm{N}$ in precipitation in most reports from China (Xiao et al., 2005; Zhang, 2006; Chen and Mulder, 2007a). The source of the high ammonium deposition is mainly thought to be the intensive agriculture covering much of the landscape between our site and the major cities. The warm climate may 

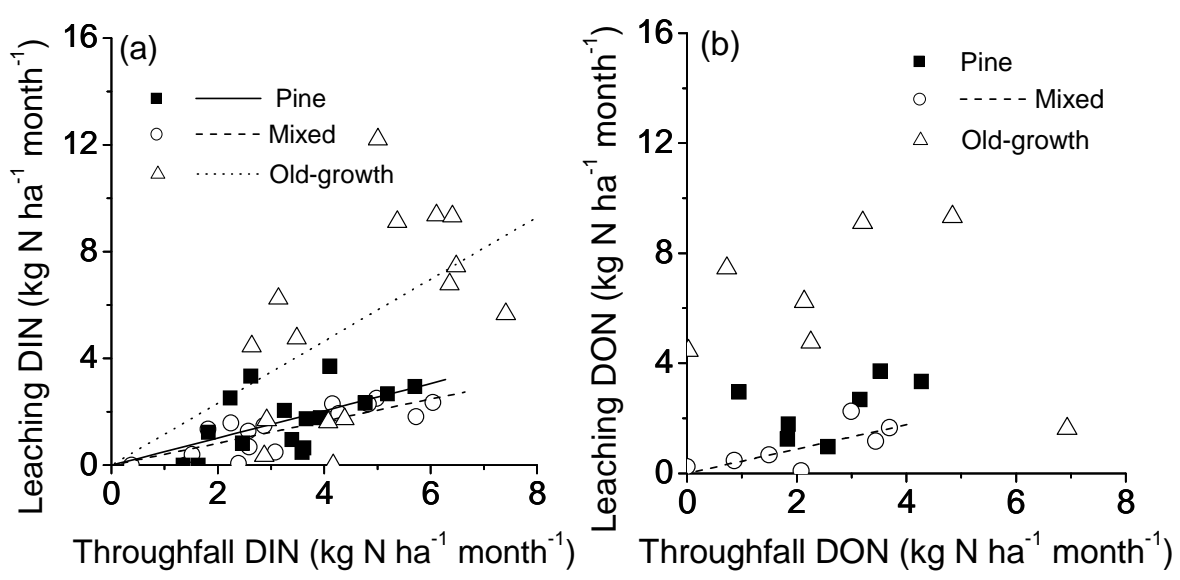

Fig. 8. Relationships between monthly solution leaching and monthly throughfall input for DIN (a) and DON (b) in the pine, mixed and old-growth forests in DHSBR of southern China. (a) Pine forest, $y=0.51 x, r^{2}=0.24, P=0.062, n=15 ;$ Mixed forest, $y=0.41 x, r^{2}=0.63$, $P<0.001, n=15$; Old-growth forest, $y=1.16 x, r^{2}=0.33, P=0.021, n=15$. (b) Mixed forest, $y=0.44 x, r^{2}=0.54, P=0.037, n=7$. In the pine and old-growth forest, the relationships were not significant. DON concentration was measured in 2005 only.

increase the emission rates above those observed in temperate regions, but emission inventories for the region are lacking. The oxidized $\mathrm{N}$ emissions from the industrialized areas in China are better documented. For instance, Richter et al. (2005) observed a highly significant increase of about $50 \%$ in the tropospheric $\mathrm{NO}_{2}$ over south China using satellite instruments.

In addition to the DIN input, a surprisingly high DON input of $17.8 \mathrm{~N} \mathrm{ha}^{-1} \mathrm{yr}^{-1}$ in precipitation was measured at our site. This is higher than any fluxes in precipitation reported in a global synthesis on organic $\mathrm{N}$ deposition $(0.6-10.9 \mathrm{~kg}$ $\mathrm{N} \mathrm{ha}^{-1} \mathrm{yr}^{-1}$ with a median of $2.2 \mathrm{~kg} \mathrm{~N} \mathrm{ha}^{-1} \mathrm{yr}^{-1}$; Neff et al., 2002). We therefore checked the quality of the measurements, but found no reason to doubt the results since both bulk samples and the wet-only samples revealed the same high concentrations (mean $1.1 \mathrm{mg} \mathrm{N} \mathrm{L}^{-1}$ ). Further, we identified a study from China with a similar high DON input (on average $15.8 \mathrm{~kg} \mathrm{~N} \mathrm{ha}^{-1} \mathrm{yr}^{-1}$ ) for 11 sites in Zhangzhou city of Fujian province, with total mean DON concentration of $1.1 \mathrm{mg} \mathrm{N} \mathrm{L}^{-1}$ and mean total $\mathrm{N}$ input of $53 \mathrm{~kg} \mathrm{~N}$ $\mathrm{ha}^{-1} \mathrm{yr}^{-1}$ (Xiao, 2005). A very recent study from Japan reported $10.1 \mathrm{~kg} \mathrm{~N} \mathrm{ha}^{-1} \mathrm{yr}^{-1}$ of DON in precipitation in an intensive agricultural area (Ham and Tamiya, 2006). Our results combined with the observation in Zhangzhou suggest that high DON deposition does exist in the heavily air polluted regions in China, and so we need to consider this additional input in environmental studies. Future studies should identify the sources and investigate the formation of DON in precipitation.

Our data showed that DON concentration had a different seasonal fluctuation than DIN (Figs. 2-4), and it did not correlate with either $\mathrm{NH}_{4}^{+}$or $\mathrm{NO}_{3}^{-}$concentration, which indicate that DIN and DON might have different sources. The synthesis by Neff et al. (2002) also revealed that there were no strong correlations between $\mathrm{DON}$ and $\mathrm{NH}_{4}^{+}$or $\mathrm{NO}_{3}^{-}$. Conceptually, atmospheric organic $\mathrm{N}$ (AON), which we measured as DON in precipitation and throughfall, can be divided into three types of nitrogen: organic nitrate, reduced AON and biological/terrestrial AON (Neff et al., 2002). The biological/terrestrial AON refers to biological and particulate forms of organic $\mathrm{N}$ including bacteria, dust particles and pollen (Neff et al., 2002). While we find only negligible dry deposition of DON (Fig. 4) at our study site, these particulate forms are probably a minor source at least in dry form. Reduced AON compounds (e.g. from intensive agricultural activities) may form a significant contribution to DON deposition at our site, as suggested in a study in Japan (Ham and Tamiya, 2006). Organic nitrates are oxidized end products of reactions of hydrocarbons with $\mathrm{NO}_{X}\left(\mathrm{NO}+\mathrm{NO}_{2}\right)$ in polluted air masses (Neff et al., 2002) such as those occurring over southern China (Richter et al., 2005). Thus organic nitrates are also a likely contributor to the high DON deposition observed at our site.

\subsection{Throughfall $\mathrm{N}$}

In temperate forests under high levels of $\mathrm{N}$ deposition, throughfall $\mathrm{N}$ is generally found to be higher than bulk precipitation $\mathrm{N}$ due to the filtering effect of the forest canopy on dry particles and gases, and conifers tend to have higher throughfall $\mathrm{N}$ input than broadleaf forests (Kristensen et al., 2004). However, this pattern was different from our results presented here, where a considerable DIN uptake (5 to $9 \mathrm{~kg} \mathrm{~N} \mathrm{ha}^{-1} \mathrm{yr}^{-1}$ ) was observed for the conifer-dominant canopies in the pine and mixed forests, representing from $15 \%$ to $28 \%$ of their respective DIN input in precipitation (Table 2). Our results are, however, in agreement with the observation in two fir forests in Fujian, China, where a decrease in DIN from precipitation to throughfall was reported 
(Fan and Hong, 2001). In contrast, the old-growth forest with a broadleaf canopy exhibited a slight increase or no change in $\mathrm{N}$ fluxes after the interaction with canopy (Table 2). A previous study also showed that the total $\mathrm{N}$ input in throughfall of this old-growth forest $\left(39.2 \mathrm{~kg} \mathrm{~N} \mathrm{ha}^{-1} \mathrm{yr}^{-1}\right.$ ) was slightly greater than that in precipitation $(35.7 \mathrm{~kg} \mathrm{~N}$ $\mathrm{ha}^{-1} \mathrm{yr}^{-1}$, Huang et al., 1994). Adding the DON fluxes to the canopy balance did not change the pattern of canopy uptake and release among the three forests, since the DON flux in throughfall was close to that of the precipitation and the minor differences followed the trend of DIN (Table 2).

The climatologic data from the weather station showed that total annual precipitation was 1327 and $1657 \mathrm{~mm}$ in 2004 and 2005, respectively (Table 2), both were below the long-term average precipitation of $1997 \mathrm{~mm}$. Furthermore, the rain in both years fell almost exclusively in the period from March to September (83\% of the annual precipitation in 2004 and $100 \%$ in 2005, Fig. 1). This precipitation pattern in the study period may have led to an underestimation of the total DIN deposition to the canopies because there might have been some dry deposition in the dry season (from October 2004 to February 2005), which was not included in our estimate. Unfortunately the very low amounts of rain made it difficult to obtain uncontaminated throughfall samples for the dry season in these particular years. Although we might slightly underestimate the total throughfall $\mathrm{N}$ deposition it was still higher $\left(22-35 \mathrm{~kg} \mathrm{~N} \mathrm{ha}^{-1} \mathrm{yr}^{-1}\right.$ ) than most observations of throughfall $\mathrm{N}$ fluxes in Europe and North America (Kristensen et al., 2004; Campbell et al., 2004).

\subsection{Impacts of $\mathrm{N}$ deposition on $\mathrm{N}$ leaching}

In forest ecosystems, throughfall fluxes of $\mathrm{N}$ are often used as a first approximation of the total deposition (Gundersen et al., 2006). Several studies show that increased $\mathrm{NO}_{3}^{-}-\mathrm{N}$ leaching starts to occur in temperate and boreal forest when the throughfall $\mathrm{N}$ input exceeds $10 \mathrm{~kg} \mathrm{~N} \mathrm{ha}^{-1} \mathrm{yr}^{-1}$ and always occurs above $25 \mathrm{~kg} \mathrm{~N} \mathrm{ha}^{-1} \mathrm{yr}^{-1}$ (Aber et al. 2003; Gundersen et al., 2006). With the $\mathrm{N}$ deposition well above these thresholds in our study forests, one might expect high $\mathrm{N}$ leaching. The old-growth forest leached up to $37-42 \mathrm{~kg}$ $\mathrm{NO}_{3}^{-}-\mathrm{N} \mathrm{ha}^{-1} \mathrm{yr}^{-1}$ below the surface $20 \mathrm{~cm}$ soil layer (Table 2), which is substantially higher than those in almost all natural forests investigated in China (Gan et al., 1995; Chen et al., 1997; Sha et al., 2002). For example, leaching losses were found to be $1.4 \mathrm{~kg} \mathrm{~N} h a^{-1}$ year $^{-1}$ at the $25 \mathrm{~cm}$ depth from a mountain evergreen broadleaf forest in Ailaoshan of Yunnan (Gan et al., 1995), $5.9 \mathrm{~kg} \mathrm{~N} \mathrm{ha}^{-1} \mathrm{yr}^{-1}$ in a seasonal rain forest in Xishuanbanna of Yunan (Sha et al., 2002), and $6.1 \mathrm{~kg} \mathrm{~N} \mathrm{ha}^{-1} \mathrm{yr}^{-1}$ in a mountain rain forest in Jiangfengling of Hainan (Chen et al., 1997), respectively. These forests received relatively low $\mathrm{N}$ deposition, ranging from 8.9 to $14.2 \mathrm{~kg} \mathrm{~N} \mathrm{ha}^{-1} \mathrm{yr}^{-1}$. The DIN losses in leaching in our study sites were also higher than most reported data in Europe and North America (Gundersen et al., 2006). In addi- tion, we found that the $\mathrm{N}$ leaching loss from the old growth forest was higher than that observed 15 years ago $(27.5 \mathrm{~kg} \mathrm{~N}$ $\mathrm{ha}^{-1} \mathrm{yr}^{-1}$ ), where $8 \mathrm{~kg} \mathrm{~N} \mathrm{ha}^{-1} \mathrm{yr}^{-1}$ was still retained in the ecosystem (Huang et al., 1994).

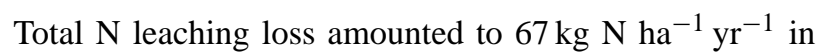
the old-growth forest, which exceeded the TDN inputs in throughfall $\left(52 \mathrm{~kg} \mathrm{~N} \mathrm{ha}^{-1} \mathrm{yr}^{-1}\right)$ or precipitation $(50 \mathrm{~kg} \mathrm{~N}$ $\mathrm{ha}^{-1} \mathrm{yr}^{-1}$ ) by 15 or $17 \mathrm{~kg} \mathrm{~N} \mathrm{ha}^{-1} \mathrm{yr}^{-1}$ (Tables 2, 3). The results above indicate that the upper $20 \mathrm{~cm}$ soil is well saturated with $\mathrm{N}$. It might also result from "mining" of the preexisting organic N (McDowell et al., 2004) and/or reduced $\mathrm{N}$ uptake by vegetations (see below). Compared to the oldgrowth forest, the two young forests lost less TDN $(22-29 \mathrm{~kg}$ $\mathrm{N} \mathrm{ha}^{-1} \mathrm{yr}^{-1}$ ) and thereby retained more $\mathrm{N}$ from the precipitation (approximately $21-28 \mathrm{~kg} \mathrm{~N} \mathrm{ha}^{-1} \mathrm{yr}^{-1}$, Table 3 ) in the plants or soils. These two forests have more N-poor soils (higher $\mathrm{C} / \mathrm{N}$ ratios, Table 1) than the old-growth forest, which may suggest that the capacity to retain $\mathrm{N}$ depended largely on ecosystem N status as proposed by Gundersen et al. (1998).

The $\mathrm{N}$ retained in forest ecosystems mainly ends up in the plant biomass and the soil organic matter (SOM) (Nadelhoffer et al., 2004). In the aggrading pine forest where human disturbance had ceased, recent estimate suggests that the canopy tree, the understory plants and standing floor litter accumulated 9.1, 6.0 and $6.5 \mathrm{~kg} \mathrm{~N}^{-1} \mathrm{yr}^{-1}$, respectively, during the period from 1990 to 2000 (Mo et al., 2004). The $22 \mathrm{~kg}$ $\mathrm{N} \mathrm{ha}^{-1} \mathrm{yr}^{-1}$ sequestrated in these three aboveground pools, which is sufficient to explain the observed $21 \mathrm{~kg} \mathrm{~N} \mathrm{ha}^{-1} \mathrm{yr}^{-1}$ that was retained above the upper $20 \mathrm{~cm}$ soil (Table 3). In the mixed forest, $\mathrm{N}$ accumulation in the plant biomass and the increasing litter layer were probably higher than in the pine forest, due to higher litter production and higher foliar $\mathrm{N}$ concentration (Mo et al., 2007), and might as well account for the $28 \mathrm{~kg} \mathrm{~N} \mathrm{ha}^{-1} \mathrm{yr}^{-1}$ retained in this forest (Table 3). The accumulation of plant biomass and plant derived litter is thus the dominant sink for $\mathrm{N}$ in these young forests, whereas the $\mathrm{N}$ sink in the mineral soil SOM seems minor. In the old-growth forest, high $\mathrm{N}$ leaching losses may be a function of low increment that would diminish the ability of the vegetation to retain $\mathrm{N}$. Recent monitoring suggested that this forest might be experiencing a decline in tree productivity (Zhang et al., 2002; Guan et al., 2004). The biomass of woody plants ( $>1 \mathrm{~cm}$ in DBH) declined by $15.2 \%$ from 1994 to 1999 (Zhang et al., 2002). A decreasing trend of litter production was also found over the last two decades (Guan et al., 2004). From our present study we cannot conclude if the declining growth is the reason for reduced $\mathrm{N}$ retention or if the high $\mathrm{N}$ load and the $\mathrm{N}$ saturation of this natural stand is the cause of the reduced growth. A mean $\mathrm{NO}_{3}^{-}-\mathrm{N}$ leaching for the two years of observation of $39 \mathrm{~kg} \mathrm{~N} \mathrm{ha}^{-1} \mathrm{yr}^{-1}$ imposed a strong acidification of the upper $20 \mathrm{~cm}$ soil equivalent to $2.8 \mathrm{kmol}$ of $\mathrm{H}^{+} \mathrm{ha}^{-1} \mathrm{yr}^{-1}$ (Gundersen et al., 2006) that may potentially affect plant growth and nutrient uptake through base cation leaching. 
The pattern of $\mathrm{N}$ retention (plant $\mathrm{N}$ demand being the major $\mathrm{N}$ sink for increased $\mathrm{N}$ deposition) in these young subtropical forests seem to be different from those in the temperate and boreal zone, where the forests have a high retention efficiency for throughfall (or experimentally added) $\mathrm{N}$ (Aber et al., 1998; Gundersen et al., 1998; MacDonald et al., 2002). A major fraction of the input was incorporated into the large organic matter pool of the forest floor (Nadelhoffer et al., 2004). We suspect that the thinner or the lack of forest floor horizon in our forests (including the old growth) may contribute to the reduced retention capacity in soils compared to the temperate sites.

Further, reduced tree growth, as forests are aging or possibly as a consequence of $\mathrm{N}$ saturation as indicated in the old-growth forest of our study, may with time increase the fraction of $\mathrm{N}$ loss more generally in the region. Additional research is, however, needed to determine the partitioning of anthropogenic $\mathrm{N}$ in soil and plant in other polluted forests of southern China, with differing disturbance histories, floristic compositions, and soils, so that these suggested patterns can be confirmed.

\subsection{Seasonality of DIN deposition and leaching}

Temperate forests are generally N-limited and cycle DIN tightly, and leaching loss is thought to be under biological control. Therefore, the concentration and seasonality of leached $\mathrm{NO}_{3}^{-}$in stream water has been taken as a primary indicator for the $\mathrm{N}$ excess in forested catchments in Europe and North America (Stoddard, 1994). The early stages of $\mathrm{N}$ excess are characterized by apparent seasonality and increases in the severity and frequency of $\mathrm{NO}_{3}^{-}$episodes in the growing season. The later stages of $\mathrm{N}$ excess are marked by elevated concentrations of $\mathrm{NO}_{3}^{-}$even at base flow (Stoddard, 1994). In this study, a considerable amount of DIN (14-48 $\mathrm{kg} \mathrm{N} \mathrm{ha}^{-1} \mathrm{yr}^{-1}$ ) was leached from all three forests, despite the aggrading condition of the two young forests (Table 3), indicating that current $\mathrm{N}$ deposition seems sufficient for the biotic $\mathrm{N}$ demand by plants and microbes. Moreover, abundant precipitation in the rainy season is likely to aggravate $\mathrm{N}$ leaching loss. We found a good correlation between throughfall and leaching for monthly DIN concentration as well as flux (Fig. 8a), indicating that part of leaching losses could be hydrologically driven in these forests.

In the old-growth forest, a somewhat different seasonal variation in soil solution $\mathrm{NO}_{3}^{-}$was observed with markedly increased $\mathrm{NO}_{3}^{-}$concentrations in some months with high precipitation, whereas no such increase was found in the young forests (Fig. 3). This increase in $\mathrm{NO}_{3}^{-}$concentrations may be caused by increased net mineralization and nitrification stimulated by abundant precipitation in combination with high temperature (Fig. 1). Such climatic conditions may also have stimulated net mineralization rate in the two young forests, but a concurrent increase in plant $\mathrm{N}$ uptake most probably limited the loss from soil solution. This result indicates that episodic climatic events are likely to contribute more to DIN leaching losses in N-rich forest than in less Nrich forests.

\subsection{Importance of DON}

The importance of DON in ecosystem nutrient budgets has been largely ignored probably due to poor analytical methods (Campbell et al., 2000). However, a number of recent studies in temperate climates have shown that DON can comprise about $50 \%$ or more of the TDN flux in throughfall, soil leachate, and stream water in both low and moderate $\mathrm{N}$ deposition areas (McHale et al., 2000; Perakis and Hedin, 2002; McDowell et al., 2004). In this study, DON is also shown to be a very important component in the $\mathrm{N}$ cycle under high $\mathrm{N}$ deposition (Table 2). In 2005, $17.8 \mathrm{~kg} \mathrm{~N}^{-1} \mathrm{yr}^{-1}$ was deposited to our study forests as DON, comprising $36 \%$ of TDN input in precipitation. Comparable DON fluxes (14.6 to $20.1 \mathrm{~kg} \mathrm{~N} \mathrm{ha}^{-1} \mathrm{yr}^{-1}$ ) were found in throughfall. In soil solution, from 6.5 to $16.9 \mathrm{~kg} \mathrm{~N} \mathrm{ha}^{-1} \mathrm{yr}^{-1}$ left the systems as DON, and made up $28-38 \%$ of TDN output. The absolute amount and percentage of DON in $\mathrm{N}$ fluxes in this study suggested that inclusion of DON is critical in assessing $\mathrm{N}$ dynamics.

We note that the concentrations and fluxes of DON in precipitation, throughfall, as well as soil solution leaching from the forests that we investigated are markedly higher than those reported in most other forests (Michalzik et al., 2001; Perakis and Hedin, 2002), although DON might be further adsorbed in underlying mineral soils and be processed near or in stream. For instance, in pristine temperate forest watersheds, DON is the dominant form of $\mathrm{N}$ loss, but usually DON concentrations are below $0.6 \mathrm{mg} \mathrm{N} \mathrm{L}^{-1}$ and the loss in the order of $1-3 \mathrm{~kg} \mathrm{~N} \mathrm{ha}^{-1}$ year $^{-1}$ (Gundersen et al., 2006). A recent study from the humid tropics in North Thailand estimated the DON leaching loss in forests to be only $0.5-0.8 \mathrm{~kg}$ $\mathrm{N} \mathrm{ha}^{-1} \mathrm{yr}^{-1}$ (Möller et al., 2005), which was comparable to the input of DON with precipitation $\left(1.1 \mathrm{~kg} \mathrm{~N} \mathrm{ha}^{-1} \mathrm{yr}^{-1}\right)$ in that area. High fluxes of DON were found in only a few sites in the compilation of Michalzik et al. (2001) for temperate forests. However, despite the high concentrations and fluxes in our study, we found the proportions of DON in TDN (28$40 \%$ ) in precipitation, throughfall and solution were well within the range for the previous reports (Michalzik et al., 2001; Neff et al., 2002, Cornell et al., 2003; Ham et al., 2007).

Throughfall DON may be a source of soil solution DON at our sites. But a significant relationship between monthly DON leaching and throughfall DON input was only found in one of three forests (Fig. 8b). This suggests that soil solution DON was influenced either by soil sources of DON (decomposition of litter and soil organic matter, plant exudates, fine-root and mycorrhizal turnover, and the waste products of macro and microorganisms), or by DON sinks (e.g. adsorption in organic and mineral soil horizons), or both. 


\section{Conclusions and perspectives}

Our measurements of $\mathrm{N}$ deposition in precipitation and forest throughfall confirm that atmospheric $\mathrm{N}$ input (up to $50 \mathrm{~kg} \mathrm{~N}$ $\mathrm{ha}^{-1} \mathrm{yr}^{-1}$ ) in this region of south China is among the highest in world and previous data suggests that it has persisted for more than a decade. The contribution of DON $(18 \mathrm{~kg} \mathrm{~N}$ $\mathrm{ha}^{-1} \mathrm{yr}^{-1}$ ) is the highest ever reported in precipitation and this flux needs more research to detail sources, pathways as well as its potential effects. Most $\mathrm{N}$ deposition was recorded in the rainy season in precipitation with some canopy retention in the pine and mixed forests.

A considerable amount of DIN (14-48 $\left.\mathrm{kg} \mathrm{N} \mathrm{ha}^{-1} \mathrm{yr}^{-1}\right)$ regardless of forest age, vegetation composition and land-use history was leached out of the upper $20 \mathrm{~cm}$ soil where a majority of roots grow, indicating that present atmospheric $\mathrm{N}$ loading may have already exceeded the plant and microbial $\mathrm{N}$ demand in the study region. A higher $\mathrm{N}$ retention in two young forests could be explained by the tree growth and litter accumulation, which on the other hand, suggests a limited retention capacity of the mineral soil. The $\mathrm{N}$-excess was aggravated in the old-growth forest, where no retention but rather a net loss from the soil pool was indicated.

The consequences of the elevated $\mathrm{N}$ deposition for forests in this region still need to be further investigated. Nevertheless, the nitrate leaching we observed has caused soil acidification that may impair forest nutrition balance. Forests in the region have been used heavily in the past and thus younger stands, like the pine and mixed forests in our study may still be able to retain a fraction of the atmospheric deposited $\mathrm{N}$. However, hydrologically driven $\mathrm{N}$ leaching will occur in the growing season regardless of the forest $\mathrm{N}$ status due to the abundant rainy season precipitation in the region.

Acknowledgements. This study was founded by the National Natural Science Foundation of China (No. 40703030; 30670392), postdoctorial fellowship of South China Botanical Garden, CAS (200611), Key Project of Chinese Academy of Sciences Knowledge Innovation Program (KZCX2-YW-432-2, KSCX2-SW-133), and the Provincial Natural Science Foundation of Guangdong (No. 7006915). We thank D. J. Li, H. Fang, X. K. Lu, X. M. Fang, J. R. Long and others for assistance in the field and laboratory. We especially thank M. Yoh, S. Brown and G. Y. Zhou for their advice throughout the study and thank L. O. Nilsson and three anonymous referees for their improvement of manuscript.

Edited by: J. Kesselmeier

\section{References}

Aas, W., Shao, M., Jin, L., Larssen, T., Zhao, D. W., Xiang, R. J., Zhang, J. H., Xiao, J. S., and Duan, L.: Air concentrations and wet deposition of major inorganic ions at five non-urban sites in China, 2001-2003. Atmos. Environ., 41, 1706-1716, 2007.

Aber, J. D., Goodale, C. L., Ollinger, S. V., Smith, M. L., Magill, A. H., Martin, M. E., and Stoddard, J. L.: Is nitrogen altering the nitrogen status of northeastern forests?, BioScience, 53, 375390, 2003.

Aber, J. D., McDowell, W., Nadelhoffer, K., Magill, A., Berntsen, G., Kamakea, M., McNulty, S., Currie, W., Rustad, L., and Fernandez, I.: Nitrogen saturation in temperate forest ecosystems hypothesis revisited, BioScience, 48, 921-934, 1998.

Aber, J. D., Nadelhoffer, K. J., Steudler, P., and Melillo, J. M.: Nitrogen saturation in northern forest ecosystems - hypotheses and implications. BioScience, 39, 378-386, 1989.

Campbell, J. L., Hornbeck, J. W., Mitchell, M. J., Adams, M. B., Castro, M. S., Driscoll, C. T., Kahl, J. S., Kochenderfer, J. N., Likens, G. E., Lynch, J. A., Murdoch, P. S., Nelson, S. J., and Shanley, J. B.: Input-output budgets of inorganic nitrogen for 24 forest watersheds in the northeastern United States: a review, Water Air Soil Pollut., 151, 373-396, 2004.

Campell, J. L., Hornbeck, J. W., McDowell, W. H., Buso, D. C., Shanley, J. B., and Likens, G. E.: Dissolved organic nitrogen budgets for upland, forested ecosystems in New England, Biogeochemistry, 49, 123-142, 2000.

Chen, B. F., Zhou, G. Y., Zeng, Q. B., Li, Y. D., and Wu, Z. M.: Study on hydrochemical cycling in tropical mountain rain forest ecosystem, Forest Res., 10, 111-117, 1997.

Chen, X. Y. and Mulder, J.: Atmospheric deposition of nitrogen at five subtropical forested sites in South China, Sci. Total Environ., 378, 317-330, 2007a.

Chen, X. Y. and Mulder, J.: Indicators for nitrogen status and leaching in subtropical forest ecosystems, South China, Biogeochemistry, 82, 165-180, 2007b.

Cornell S. E., Jickell, T. D., Cape, J. N., Rowland, A. P., and Duce, R. A.: Organic nitrogen deposition on land and coastal environments: a review of methods and data, Atmos. Environ., 37, 2173 2191, 2003.

Dise, N. B., Matzner, E., and Forsius, M.: Evaluation of organic horizon $\mathrm{C}: \mathrm{N}$ ratio as an indicator of nitrate leaching in conifer forests across Europe, Environ. Pollut., 102, 453-456, 1998.

Fan, H. B. and Hong, W.: Estimation of dry deposition and canopy exchange in Chinese fir plantation, Forest Ecol. Manag., 147, 99-107, 2001.

Fang, Y. T., Yoh, M., Mo, J. M., Gundersen, P., and Zhou, G. Y.: Response of nitrogen leaching to simulated nitrogen deposition in a disturbed and a mature forest in southern China, Pedosphere, accepted, 2008.

Fang, Y. T., Zhu, W. X., Mo, J. M., Zhou, G. Y., and Gundersen, P.: Dynamics of soil inorganic nitrogen and their responses to nitrogen additions in three subtropical forests, south China, J. Environ. Sci.-China, 18, 752-759, 2006.

Fenn, M. E., Poth, M. A., Aber, J. D., Baron, J. S., Bormann, B. T., Johnson, D. W., Lemly, A. D., McNulty, S. G., Ryan, D. F., and Stottlemyer, R.: Nitrogen excess in North American ecosystems: Predisposing factors, ecosystem responses, and management strategies, Ecol. Appl. 8, 706-733, 1998.

Galloway, J., Cowling, E., and Kessler, E.: Reactive nitrogen, Ambio, 31, 59, 2002.

Gan, J. M., Xue, J. Y., and Zhao, H. K.: A preliminary study on changes of nutrient import and export in the process of rainfall in the Ailao Mountains region of Yunnan Province, J. Natural Res., 10, 43-50, 1995.

Guan, L. L., Zhou, G. Y., Zhang, D. Q., Liu, J. X., and Zhang, Q. M.: Twenty years of litterfall dynamics in subtropical evergreen 
broad-leaved forests at the Dinghushan forest ecosystem research station, Acta Phytoecol. Sin., 28, 449-456, 2004.

Gundersen, P., Emmett, B. A., Kjønaas, O. J., Koopmans, C., and Tietema, A.: Impact of nitrogen deposition on nitrogen cycling in forest:a synthesis of NITREX data, Forest Ecol. Manag., 101, 37-55, 1998.

Gundersen, P., Schmidt, I. K., and Raulund-Rasmussen, K.: Leaching of nitrate from temperate forests - effects of air pollution and forest management, Environ. Rev., 14, 1-57, 2006.

Hall, S. J. and Matson, P. A.: Nutrient status of tropical rain forests influences soil $\mathrm{N}$ dynamics after $\mathrm{N}$ additions, Ecol. Monogr., 73, 107-129, 2003.

Ham, Y. S., Tamiya, S., and Choi, I. S.: Contribution of dissolved organic nitrogen deposition to nitrogen saturation in a forested mountainous watershed in Tsukui, Central Japan, Water Air Soil Pollut., 178, 113-120, 2006.

Ham, Y. S. and Tamiya, S.: Contribution of dissolved organic nitrogen deposition to total dissolved nitrogen deposition under intensive agricultural activities, Water Air Soil Pollut., 178, 5-13, 2006.

He, J. H., Chen, Z. Q., and Liang, Y. A.: The soil of Ding Hu Shan, Trop. Subtrop. For. Ecosys., 1, 25-38, 1982.

Huang, Z. F. and Fan, Z. G.: The climate of Ding Hu Shan, Trop. Subtrop. For. Ecosys., 1, 11-23, 1982.

Huang, Z. L., Ding, M. M., Zhang, Z. P., and Yi, W. M.: The hydrological processes and nitrogen dynamics in a monsoon evergreen broad-leafed forest of Dinghu shan, Acta Phytoecol. Sinic., 18, 194-199, 1994.

Kristensen, H. L., Gundersen, P., Callesen, I., and Reinds, G.: Throughfall nitrogen deposition has different impacts on soil solution nitrate concentration in European coniferous and deciduous forests, Ecosystems, 7, 180-192, 2004.

Liu, G. S., Jiang, N. H., and Zhang, L. D.: Soil physical and chemical analysis and description of soil profiles, Standards Press of China, Beijing, 1996.

Lohse, A. L. and Matson, P.: Consequences of nitrogen additions for soil processes and solution losses from wet tropical forests, Ecol. Appl., 15, 1629-1648, 2005.

Lovett, G. M., Weather, K. C., and Arthur, M. A.: Control of nitrogen loss from forested watersheds by soil carbon: nitrogen ratio and tree species composition, Ecosystems, 5, 712-718, 2002.

Luo, L. C., Qin, B. Q., Song, Y. Z., and Yang, L. Y.: Seasonal and regional variations in precipitation chemistry in the Lake Taihu Basin, China, Atmos. Environ., 41, 2674-2679, 2007.

MacDonald, J. A., Dise, N. B., Matzner, E., Armbruster, M., Gundersen, P., and Forsius, M.: Nitrogen input together with ecosystem nitrogen enrichment predict nitrate leaching from European forests, Global Change Biol., 8, 1028-1033, 2002.

Magill, A. H., Aber, J. D., Currie, W. S., Nadelhoffer, K. J., Martin, M. E., McDowell, W. H., Melillo, J. M., and Steudler, P.: Ecosystem response to 15 years of chronic nitrogen additions at the Harvard Forest LTER, Massachusetts, USA, Forest Ecol. Manag., 196, 7-28, 2004.

Matson, P. A., McDowell, W. H., Townsend, A. R., and Vitousek, P. M.: The globalization of $\mathrm{N}$ deposition: ecosystem consequences in tropical environments, Biogeochemistry, 46, 67-83, 1999.

McDowell, W. H., Magill, A. H., Aitkenhead-Peterson, J. A., Aber, J. D., Merriam, J. L., and Kaushal, S. S.: Effects of chronic nitrogen amendment on dissolved organic matter and inorganic ni- trogen in soil solution, Forest Ecol. Manag., 196, 29-41, 2004.

Michalzik, B., Kalbitz, K., Park, J. H., Solinger, S., and Matzner, E.: Fluxes and concentrations of dissolved organic carbon and nitrogen - a synthesis for temperate forests, Biogeochemistry, 52, 173-205, 2001.

Mo, J. M., Brown, S., Peng, S. L., and Kong, G. H.: Nitrogen availability in disturbed, rehabilitated and mature forests of tropical China, Forest Ecol. Manag., 175, 573-583, 2003.

Mo, J. M., Brown, S., Xue, J. H., Fang, Y. T., Li, Z. A., Li, D. J., and Dong, S. F.: Response of nutrient dynamics of decomposing pine (Pinus massoniana) needles to simulated $\mathrm{N}$ deposition in a disturbed and a rehabilitated forest in tropical China, Ecol. Res., 22, 649-658, 2007.

Mo, J. M., Brown, S., Xue, J. H, Fang, Y. T., and Li, Z. A.: Response of litter decomposition to simulated $\mathrm{N}$ deposition in disturbed, rehabilitated and mature forests in subtropical China, Plant Soil, 282, 135-151, 2006.

Mo, J. M., Fang, Y. T., Zhang, D. Q., Kong, G. H., and Fen, Z. N.: Effects of rainfall reallocation on nutrient dynamic of a pine forest in Dinghushan, Guihaia, 22, 529-533, 2002.

Mo, J. M., Peng, S. L., Brown, S., Kong, G. H., and Fang, Y. T.: Nutrient dynamics in response to harvesting practices in a pine forest of subtropical China, Acta Phytoecol. Sin., 28, 810-822, 2004.

Möller, A., Kaiser, K., and Guggenberger, G.: Dissolved organic carbon and nitrogen in precipitation, throughfall, soil solution, and stream water of the tropical highlands in northern Thailand, J Plant Nutr. Soil Sci., 168, 649-659, 2005.

Nadelhoffer, K. J., Colman, B. P., Currie, W. S., Magill, A., and Aber, J. D.: Decadal-scale fates of ${ }^{15} \mathrm{~N}$ tracers added to oak and pine stands under ambient and elevated $\mathrm{N}$ inputs at the Harvard Forest (USA), Forest Ecol. Manag., 196, 89-107, 2004.

Neff, J. C., Holland, E. A., Dentener, F. J., Mcdowell, W. H., and Russell, K. M.: The origin, composition and rates of organic nitrogen deposition: A missing piece of the nitrogen cycle?, Biogeochemistry, 57/58, 99-136, 2002.

Ohte, N., Mitchell, M. J., Shibata, H., Tokuchi, N., Toda, H., and Iwatsubo, G.: Comparative evaluation on nitrogen saturation of forest catchements in Japan and Northeastern United States, Water Air Soil Pollut., 130, 649-654, 2001.

Perakis, S. S. and Hedin, L. O.: Nitrogen loss from unpolluted South American forests mainly via dissolved organic compounds, Nature, 415, 416-419, 2002.

Richter, A., Burrows, J. P., Nub, H., Granier, C., and Niemeier, U.: Increase in tropospheric nitrogen dioxide over China observed from space, Nature, 437, 129-132, 2005.

Sha, L. Q., Zheng, Z., Feng, Z. L., Liu, Y. H., Liu, W. J., Meng, Y., and Li, M. R.: Biogeochemical cycling of nitrogen at a tropical seasonal rain forest in Xishuanbanna, SW China, Acta Phytoecl. Sin., 26, 689-694, 2002.

Stoddard, J. L.: Long-term changes in watershed retention of nitrogen-its causes and aquatic consequences, Environ. Chem. Lakes Reservoirs, 237, 223-284, 1994.

Tang, X. L., Liu, S. G., Zhou, G. Y., Zhang, D. Q., and Zhou, C. Y.: Soil-atmospheric exchange of $\mathrm{CO}_{2}, \mathrm{CH}_{4}$, and $\mathrm{N}_{2} \mathrm{O}$ in three subtropical forest ecosystems in southern China, Global Change Biol., 12, 546-560, 2006.

Wang, Z., He, D., Song, S., Chen, S., Chen, D., and Tu, M.: The vegetation of Dinghushan Biosphere Reserve, Trop. Sub- 
trop. For. Ecosys., 1, 77-141, 1982.

Wen, D. Z., We, I. P., Kong, G. H., and Ye, W. H.: Production and turnover rate of fine roots in two lower subtropical forest sites at Dinghushan, Acta Phytoecol. Sin., 23, 361-369, 1999.

Xiao, J.: The formation and harm of $\mathrm{N}$ wet $\mathrm{N}$ deposition in Zhuangzhou city, Energy Environ., 59-61, 2005.

Zhang, X. F.: Atmospheric nitrogen wet deposition and its effects on wetland water environment of Shanghai area, Chinese J. Appl. Ecol., 17, 1099-1102, 2006.

Zhang, Y. M., Zhou, G. Y., Wen, D. Z., Zhang, D. Q., and Zhang, Q. M.: Biomass dynamics of the Castanopsis chinensis-Schima superba-Cryptocarya concinna community of monsoon evergreen broad-leaved forest in Dinghushan Reserve, Trop. Subtrop. For. Ecosys., 9, 10-17, 2002.
Zheng, X. H., Fu, C. B., Xu, X. K., Yan, X. D., Huang, Y., Han, S. H., Hu, F., and Chen, G. X.: The Asian nitrogen cycle case study, Ambio, 31, 79-87, 2002.

Zhou, G. Y. and Yan, J. H.: The influence of region atmospheric precipitation characteristics and its element inputs on the existence and development of Dinghushan forest ecosystems, Acta Ecol. Sin., 21, 2002-2012, 2001. 